\title{
Unconventional Materials Usage in Design of Vehicle Bodies
}

Karel Raz ${ }^{1}$, Jan Hora $^{2}$, Petr Pavlata ${ }^{3}$

${ }^{1}$ Regional Technological Institute, Faculty of Mechanical Engineering, University of West Bohemia. Univerzitni 8, 306 14 Plzen. Czech Republic. E-mail: kraz@rti.zcu.cz

${ }^{2}$ Sicar spol.s r.o., Masojedy 59, 28201 Cesky Brod, Czech Republic. Email: hora@sicar.cz

${ }^{3}$ Vision Consulting Automotive Ltd., Rumunska 12, 12000 Praha 2. Czech Republic. E-mail: petr.pavlata@vca.cz

This article deals with unconventional materials usage in design of vehicle bodies. Main focus is on sandwich materials (with honeycomb structure) for walls of the main body. These panels are designed from polypropylene. Joining of theses sandwich panels is also solved here by special aluminium profile. Virtual simulations and stress evaluation are used methods for design evaluating. Research is focused also on material properties testing. Tested are sandwich materials and also connecting aluminium profiles. All material properties and testing principles are here clearly described. Lower weight of vehicle body leads to possibility of floor optimization. Welded frame of floor can be lighter and strength of floor is also evaluated here. All these steps lead to lighter design with economic benefits for producer.

Keywords: Sandwich structures, Polypropylene, Stress, Vehicle body

\section{Acknowledgments}

The present contribution has been prepared under TACR project TA0403171'Modern body of emergency car with increased transport capacity and ultralight weight'.

\section{References}

[1] FOJTL, L., RUSNAKOVA, S., ZALOUDEK, M., RUSNAK, V. (2016). The Effect of Beam Curvature on Bending Properties of Sandwich Structures, In: Manufacturing Technology, Vol. 16, pp. 81-86, ISSN 1213-2489.

[2] LI, Z., YANG, X. (2011). A New Mesh Variables Mapping Method for Vehicle Crash Simulation with Considering Sheet Forming Effects, In: Advanced Material Research, Vol. 338, pp. 245-250, ISSN 10226680.

[3] JIROUTOVA, D. (2016). Methodology of Experimental Analysis of Long. Rem Monitoring of Sandwich Composite Structure by Fibre-optic Strain Gauges, In: Manufacturing Technology, Vol. 16, pp. 512-518, ISSN 12132489.

[4] CIDLINA, J., MULlER, M., VALASEK, P. (2016). Evaluation of Adhesive Bond Strength Depending on Degradation Type and Time, In: Manufacturing Technology, Vol. 16, pp. 8-12, ISSN 1213-2489.

[5] HANUS, P., SCHMIDOVA, E. (2016). Influence of the Welding Process on the Martensitic and Dual Phase High Strength Steels, In: Manufacturing Technology, Vol. 16, pp. 702-707, ISSN 1213-2489.

[6] PYDAH, A., BATRA, R.C. (2017). Crush Dynamics and Transient Deformations of Elastic-plastic Miura-ori core sandwich plates, In: Thin- Walled Structures, Vol. 115, pp. 311-322, ISSN 02638231.

[7] LI, X., ZHANG, P., WANG, Z., WU, G., ZHAO, L., (2014). Dynamic Behavior of Aluminium Honeycomb Sandwich Panels under Air Blast: Experiment and Numerical Analysis, In: Composite Structures, Vol. 108, pp. 10011008, ISSN 02638223.

[8] ARORA, H., DEL LINZ, P., DEAR, J. P. (2017). Damage and Deformation in Composite Sandwich Panels Exposed to Multiple and Single Explosive Blasts, In: International Journal of Impact Engineering, Vol. 104, pp. 95106, ISSN 0734743X.

[9] FARD, K.M., LIVANI, M. (2015). The Buckling of Truncated Conical Sandwich Panels under Axial Compression and External Pressure, In: Proceedings of the Institution of Mechanical Engineers, Part C: Journal of Mechanical Engineering Science, Vol. 229, pp. 1965-1978, ISSN 09544062. 